Accepted version of paper published in

Public Understanding of Science 2019, Vol. 28(8) 958-972 (C) The Author(s)

https://doi.org/10.1177/0963662519870692

\title{
Constructing Publics in Museums' Science Communication
}

Per Hetland, Department of Education, University of Oslo

\begin{abstract}
This article investigates how scientists at natural history museums construct publics in science communication and identifies four major constructions based on Braun and Schultz categories: the general public, the pure public, the affected public, and the partisan public. This study draws on data from 17 research scientists at two natural history research museums in Norway who were interviewed about their public outreach activities focusing on practices, settings, designated outcomes, scientists' incentives to communicate science, and, finally, the speaking positions available for the different publics; the aim was to provide an understanding of the four constructed publics in museums' science communication. When scientists construct different publics, they emphasize relevance as an important quality assurance device.

\section{Keywords}

Natural history museums, science communication, publics, relevance 


\section{Introduction}

Museums have a long history of public outreach focusing on objects, collections, and exhibitions (Cain and Rader, 2017). However:

While staff members at natural history museums insist on the enduring relevance of their collections, in reality, they rely far less than they once did on their collections to communicate science's mutable messages (2017: 211).

Consequently, the way in which museum scientists communicate when collections are not the primary vehicle has received less attention (Cain and Rader, 2017).

Science communication is a core activity of natural history research museums, along with academic education and scientific research. Sometimes referred to as the "third assignment," science communication should 1) contribute to communicating science and technology to the public, 2) contribute to innovation, and 3) ensure the participation of higher education staff in public debates (Hetland, 2014). In Norway, science communication is historically rooted in the Nordic Enlightenment of the mid1600s (Roos and Tønnesson, 2017). The third assignment is, thus, seen as an important part of the Humbolt legacy of Bildung, meaning the formation of liberal education and civic character (Kalleberg, 2011). Kalleberg (2012: 48, emphasis in original) draws a clear distinction between two academic roles: "one as experts with clients, the other as public intellectuals with citizens." The translation of science from a highly specialized language to general public knowledge has long concerned intellectuals (Berman, 1978; Broks, 2006; Dewey, 1927; Fleck, 1935/1979; Gross, 1994; LaFollette, 1990). In Denmark, according to Horst (2012), the participatory governance of science and 
technology is founded on cultural traditions of dialogue. This dialogical tradition is also well established in Norway (Hetland, 2014).

Traditionally, science communication has been strongly linked to the dissemination model, which is a "low-cost model with high visibility, claiming little participant engagement" (Hetland, 2017: 66). Because visibility in the media is often perceived as a meaningful indicator of social relevance, it is important to explore how public involvement is handled, especially in the context of increasingly open science (Fecher and Friesike, 2014).

\section{Constructing Publics}

"Publics" may be understood as both etic and emic categories. The schema that favors the deductive production of independently testable descriptions is oriented towards what has been called etic validation, i.e., the categories of the researcher, the "objective" categories (Harris, 1969: 568-604). By contrast, the schema that favors the "emergence" of phenomenologically informed descriptions of social behavior is most appropriate to emic validation because the ultimate decision about the adequacy of descriptions rests with the participants themselves. This has the advantage that descriptions produced by an observer are less likely to be mere impositions of categories and concepts that are alien to participants. The present study uses "publics" as an emic category. I am interested in how publics are understood and constructed by scientists in museums' science communication. Consequently, the emic view was sought from those who are in the business of science communication (see also Treise and Weigold, 2002). However, scientists' etic insights may also stimulate their emic understandings. 
In their study of participatory governance arrangements, Braun and Schultz (2010) likewise identified four major constructions of publics: the general public, the pure public, the affected public, and the partisan public. The general public refers to anonymous individuals; the pure public refers to concrete individuals, often "naïve citizens" as the subjects of education; the affected public refers to concrete individuals, including the authentic expert with firsthand knowledge of a specific area; and the partisan public refers to interest groups with knowledge of the landscape of possible arguments. This account "recognizes that there is not one public, but many publics that make up civil society, and it therefore recognizes that doxa is formed through participatory discourse" (Perrault, 2013: 26). Affected and partisan publics may also belong to communities of practice with clear interests in more targeted science communication (Leave and Wenger, 1991). While Braun and Schultz (2010) were mainly concerned with how we construct publics in participatory governance arrangements, I apply the four major constructions to museums' science communication. Moreover, in the Discussion section, I will provide an understanding of the four constructed with regards to practices and settings, scientists' incentives to communicate science, the speaking positions available for the different publics and, finally, the designated outcomes.

Both Trench (2008: 131) and Bucchi (2008: 69) discussed different models of expert-public interaction, identifying three general communication models that I prefer to call the dissemination, dialogue, and participation models (Hetland, 2014). To distinguish between these models, Trench (2008: 131) and Bucchi (2008: 69) refer to issues such as emphasis, aims, ideological and philosophical associations, and the orientation of science 
to the public. Although useful, this approach partly neglects the issue of understanding the publics' involvement (Hetland, 2017). There is evidence that, even where outreach activities are presumed to use other models, the dissemination model serves as their backbone (Brossard and Lewenstein, 2010; Stocklmayer, 2013). Stocklmayer attempted to map the science communication field by asking three basic questions about communicating scientific material: from whom, to or with whom, and to what end (Stocklmayer, 2013: 27). Based on these questions, she mapped science communication as a "space" in which various actors communicate.

One crucial contemporary form of involvement is citizen science (Bonney et al., 2016; Dickinson et al., 2012; Golumbic et al., 2017; Kullenberg and Kasperowski, 2016), which, in natural history research museums, is often synonymous with public participation in biodiversity mapping and crowdsourcing activities. Amateur naturalists have a long history of involvement in biodiversity mapping (Conniff, 2011). The word "amateur" has its roots in Latin (amator - lover) and is here used for persons practicing an activity without having this as a livelihood (for a longer discussion see Hetland, 2011). While some scientists use the metaphor "stamp collections" to refer to certain amateur mapping strategies, those strategies may be as diverse as professional mapping strategies (Bowker, 2000; Hetland, 2011), and, not surprisingly, the same can be said of stampcollecting strategies (Yardley, 2015). The relationship between verified knowledge, citizen science, and science is an important issue, not least because successful citizen engagement illustrates how citizens must learn the language and culture of a given science if they are to become competent (Epstein, 1996). Amateur naturalists also make crucial discoveries, as in the case of the German amateurs who discovered "insect 
Armageddon." Consequently, the relationship between amateur communities and professional science remains in flux after 200 years of development (Barton, 2003), and I concur with Nieto-Galan that "a firm distinction between experts, amateurs or dilettantes and the general public seems dubious" (Nieto-Galan, 2016: 91), not least because professional scientists also "became 'amateur' popularizers" (Nieto-Galan, 2016: 101). One important development that may have distanced natural history research museums from amateur naturalists is the study of natural history from a field science to one that increasingly takes place in laboratories (Hine, 2008; Latour, 1987).

Describing the different contexts in which scientific knowledge is communicated, Hilgartner (1990) distinguished between upstream and downstream mediation processes and concluded that "the dominant view of popularization is a serious oversimplification that cannot, on it its own terms, provide an adequate model for the process through which scientific knowledge spreads" (Hilgartner, 1990: 533). The dominant view of popularization is strongly affected by Ingelfinger's rule, first elaborated in 1969 by Franz J. Ingelfinger in The New England Journal of Medicine. In practice, Ingelfinger launched "an embargo designed to keep scientific findings out of the media until peer-reviewed and published" (Toy, 2002: 195). The application of this rule has been debated within the Norwegian academic community (Rognan, 2016). Different publics' understandings are simplified, and similar simplifications can be found within "textbook science," as noted by Fleck: "Certainty, simplicity, vividness originate in popular knowledge. That is where the expert puts his faith in this triad of knowledge. Therein lies the general epistemological significance of popular science" (Fleck, 1935/1979: 115, emphasis in 
original). Journalists often "confirm the image of science as remote, elitist, consentient, and a collection of 'success' stories” (Einsiedel, 1992: 98).

Previous studies have reported that while some scientists have high-profile interactions with their various publics in an emerging "attention economy" (Goodell, 1977; Smith et al., 2016), most do not aim for visibility for its own sake (Bentley and Kyvik, 2011; Kyvik, 2005) but appear as modest witnesses (Hetland, 2016). This is supported by the fact that face-to-face public engagement is frequently used in science communication (Besley et al., 2017). Searle simply states: "Much of scientists' one-onone and face-to-face communication would be unrecorded and unreported and yet this is how most scientists most frequently communicate with the general public, if not those who communicate the most" (Searle, 2011: 316). The importance of personal relevance (Frewer et al., 1999; Gross, 1994; Hetland, 2014; Perrault, 2013) is often overlooked, and this study therefore focuses on scientists' constructions of different publics, as the aim is always a way of enhancing relevance. As it is difficult to characterize science communication as "good" when targeted publics experience it as irrelevant, Stocklmayer's (2013) "to what end" question is central. Thus, this article starts with the premise that scientists are well aware of their targeted publics and that they try to enhance relevance for designated publics while enhancing relevance to both personal and institutional aims.

\section{The study}

This article draws on data from 17 research scientists at two natural history research museums in Norway who were interviewed about their public outreach activities; 13 were 
men, and four were women. The participants were chosen because they are representative of tenured research scientists at the two museums (the University of Oslo's Natural History Museum and the Norwegian University of Science and Technology Museum's Natural History collections). The interviewees are numbered from 1 to 17; however, seven can be identified indirectly through their activities and/or statements by people who know the museum community, and these seven were offered the opportunity to withdraw or change identifiable statements. None of them withdrew, and none of the changes made implied new meanings.

All the scientists participated in one-on-one, semi-structured interviews conducted by the author. The interviews lasted from 30 to 61 minutes (average, 44 minutes) and explored two main topics: 1) science communication with different publics and 2) how different publics are involved and/or engaged in science. More detailed questions included how they organized science communication, who they collaborated with, their training and experience in science communication, their target groups, their motivation to partake in science communication, how laypeople and/or amateurs were involved and/or engaged, and communication of process versus results. All interviews were recorded and transcribed. The transcribed interviews were coded with the help of HyperRESEARCH software for computer-assisted qualitative data analysis (CAQDAS). HyperRESEARCH is useful for organizing, managing, and analyzing a textual corpus of this size. Each interview was coded several times to test the hypotheses and facilitate a repeating comparison of the data (Hesse-Biber and Dupuis, 2000).

Science communication is studied here with the overall aim of understanding how scientists build bridges between science and society, helping publics to understand both 
the processes and results of scientific research. The main research question was: How do scientists at natural history research museums construct publics in museums' science communication? In collecting answers to this question, the aim is also to improve our understanding of how scientists communicate with the aforementioned four publics.

\section{Findings}

All interviewees were engaged in a diverse range of nonscientific groups in society. Table 1 illustrates this diversity but does not indicate the strength of the interactions, which will be described subsequently. To begin, I present some general findings before moving on to the four identified publics. 
Table 1. Nonscientific groups with whom the participating scientists interact

\begin{tabular}{|c|c|c|c|c|c|c|c|c|c|c|c|c|c|c|c|c|c|}
\hline \multirow[t]{2}{*}{ To or with whom } & \multicolumn{17}{|c|}{ Interviewee's number } \\
\hline & 1 & 2 & 3 & 4 & 5 & 6 & 7 & 8 & 9 & 10 & 11 & 12 & 13 & 14 & 15 & 16 & 17 \\
\hline \multicolumn{18}{|l|}{$\begin{array}{l}\text { The general } \\
\text { public }\end{array}$} \\
\hline $\begin{array}{l}\text { General } \\
\text { publics/visitors }\end{array}$ & $x$ & $\mathrm{x}$ & $x$ & $x$ & $x$ & $x$ & $x$ & $x$ & $x$ & $x$ & $x$ & $x$ & $x$ & $x$ & $x$ & $x$ & $x$ \\
\hline $\begin{array}{l}\text { In-house Science } \\
\text { Communication }\end{array}$ & & $x$ & & & & & $x$ & & $x$ & & $x$ & $x$ & $x$ & & & & $x$ \\
\hline \multicolumn{18}{|l|}{ The pure public } \\
\hline Children/schools & $x$ & $x$ & & & $\mathrm{x}$ & & $x$ & $x$ & $x$ & & $x$ & $x$ & $x$ & & $x$ & $x$ & $x$ \\
\hline \multicolumn{18}{|l|}{$\begin{array}{l}\text { The affected } \\
\text { public }\end{array}$} \\
\hline $\begin{array}{l}\text { Individual } \\
\text { amateurs }\end{array}$ & $x$ & $x$ & $x$ & $x$ & $x$ & & $x$ & & $x$ & $x$ & $x$ & $\mathrm{x}$ & $x$ & & $x$ & $x$ & $x$ \\
\hline $\begin{array}{l}\text { Social media } \\
\text { publics }\end{array}$ & & & & $x$ & & $x$ & $x$ & $\mathrm{x}$ & & & $x$ & $x$ & $x$ & $x$ & $x$ & & $x$ \\
\hline $\begin{array}{l}\text { Amateur } \\
\text { associations }\end{array}$ & $x$ & $x$ & $x$ & $x$ & $x$ & $x$ & $x$ & & $x$ & $x$ & $x$ & $x$ & $x$ & $x$ & $x$ & $x$ & $x$ \\
\hline \multicolumn{18}{|l|}{$\begin{array}{l}\text { The partisan } \\
\text { public }\end{array}$} \\
\hline $\begin{array}{l}\text { Species } \\
\text { Observation* }\end{array}$ & $x$ & $x$ & $x$ & & $x$ & & & & & $x$ & & $x$ & & & & & \\
\hline $\begin{array}{l}\text { Politicians/ } \\
\text { stakeholders }\end{array}$ & $x$ & & $x$ & & $x$ & $x$ & $x$ & $x$ & $x$ & $x$ & $x$ & $x$ & & $x$ & $x$ & $x$ & $x$ \\
\hline
\end{tabular}

(*Species Observation is a web portal for volunteers to record biological observations.)

All interviewees find science communication rewarding. Several mentioned that science communication has grown in importance, both for them personally and within the museum. They also stated that society expects them to be active in science 
communication, and that it factors into their applications for tenure. Apparently, it is also easier to undertake science communication later in one's career, especially after securing tenure. However, supervisors, such as Interviewee 9, also tried to turn this around: "I tell my students it is an option to do it the other way around, so that the science comes after science communication.” Despite some media anxiety among younger employees, several scientists, such as Interviewee 3, started their science communication early: "I started to use newspapers while still a master's student... Later, I became used to using newspapers, and I have also used radio and TV."

Several interviewees commented on the lack of incentives (and some disincentives) and said that science communication is not included in the financial model for universities and university museums. The disincentives relate mainly to the negative comments of senior colleagues, peers, or stakeholders: "Participating in some public debates can have a personal cost. I have been threatened with lawyers" (Interviewee 15); Interviewee 15 also said, "When I was a PhD student, I got negative feedback internally; you shouldn't promote yourself. Now I have tenure, and it is more accepted." However, all the scientists said that they enjoy science communication either when doing it directly or, if they are more modest, by providing information packages to the media. Even those with a low profile reported successful acts of science communication that they found enjoyable.

Science communication also has emotional aspects associated with a certain "missionary" zeal: "For me, it is important to communicate the systematic collections. They are hidden from society at large" (Interviewee 15); or, more generally, "Working at a museum, I am able to participate more in science communication than if I were working 
in an ordinary science department" (Interviewee 9). Collections are still perceived as the backbone of natural history research museums, and most scientists emphasize that museums consider these physical specimens essential.

While both museums have in-house science communicators to facilitate science communication, most of the interviewed scientists have limited contact with them. Instead, they prefer to organize their own communication and usually use the in-house communicators only when important institutional aspects are involved: "it is usually easier to contact a journalist" (Interviewee 12), or, "I feed our SciComm officer with information when we have science weeks, and then they do the practical work" (Interviewee 11). This limited use of in-house communicators is also linked to how scientists think about their own science identities: "I represent my field of research, and,

of course, I have to represent my institution in an acceptable manner" (Interviewee 8). All interviewees stressed their scientific identities over their institutional identity, although several confirmed that their institution had told them not to forget the latter.

\section{Dissemination activities with general publics}

All interviewees communicated with general publics, and two of three communicated with children. However, the quantity varied considerably, and a few preferred not to communicate more than necessary with general publics. Successful communication with general publics was either linked to engagement on topics such as nutrition, sex, dinosaurs, and snakes, or it had to be rendered engaging by doing something unexpected, like eating things people find disgusting. Several interviewees mentioned a well-known 
TV biologist from the 1960s and 1970s who once nearly choked eating raw hagfish. In the same vein, one scientist said, "Due to increased public interest, I have become much of an expert on eating insects" (Interviewee 5). Repulsive behaviors like these fascinate different publics, but so do ordinary plants: "Once, I did a radio lecture about bananas, what kind of fruits they are. Afterward, I got an email from a guy working at a meteorological station on Spitsbergen. He told me that he'd had to scare off an ice bear, but at the same time, he was shouting to his colleagues that bananas are really a berry. Getting this kind of feedback makes me feel I have achieved something” (Interviewee 15). All the scientists found it satisfying when somebody was interested, leading to "people calling the museum. That's an underrated part of our science communication. All my direct communications with users are invisible" (Interviewee 2). As a result, general publics also engage in dialogue: "I get telephone calls every second day from laypeople-I tell them that if they want more exact answers, they have to come to the museum so that I can see the specimen" (Interviewee 7).

Several of the scientists referred to the importance of enthusiasm and surprise. To engage, one has to communicate science broadly, which has its own pitfalls: "I try to credit colleagues, but that is often too complicated for journalists, so you then have to live with being credited with a more important role than you actually had" (Interviewee 12). They are also aware that their own area of research has limited appeal outside their fields. Nevertheless, there are successes: "The journalist concluded that he should have been a botanist - then I also felt that my job was exciting" (Interviewee 15).

All the interviewees were aware that, while "some things are easy to communicate, have appeal, and are easily accessible" (Interviewee 12), other aspects of 
science are more challenging. All were asked about how they handled Ingelfinger's rule. "Some communicate results on Twitter before the manuscript is ready for publication, but we prefer to complete the refereeing process first" (Interviewee 12). Consequently, most of the scientists distinguished between results and process. In relation to results, most of them still followed the Ingelfinger rule, but when it comes to the research process, most referred to the different publics, as it is "very important to communicate process" (Interviewee 6). Several mentioned the discussion that took part when the Ida fossil papers were published in a refereed journal and to the general publics at the same time (Rognan, 2016: 51). What happened was taken as evidence that science communication can have high costs. Process was considered important by the interviewees for two reasons: it is often considered more "dramatic and exciting" and to understand process is to understand the dynamic aspects of science: "We have to tell the public that there is still a lot of research to be done" (Interviewee 15).

\section{Dissemination activities and dialogues with pure publics}

Despite their interest, very few of the participants have any formal training in science communication; they have learned by doing, and they emphasize the importance of personal engagement and enthusiasm. Science communication was seen to have some important consequences; among these, communication and interaction with different publics has helped scientists to broaden their interests and communicate in areas broader than their own research: 
I have had to learn about things beyond my own field of research. When you talk to kids, you have to know something about everything (Interviewee 7).

As well as being an important gateway to new research projects, science communication has its own rewards: "The only time a scientist might feel like a pop star is when they have 400 children in the auditorium, with nobody fighting" (Interviewee 9). They may also be motivated by a general worry: "My children tell me that many no longer believe in evolution. We have a job to do; we live in a bubble where everybody believes in evolution" (Interviewee 16).

Children as publics generated some strong reactions: "Children have the lowest status within science communication, but through contact with children, I know that stories are most important for them because they will remember those stories for the rest of their lives" (Interviewee 9). "Writing books for children kills your credibility. We feel unappreciated by our more serious colleagues when we do science communication that targets children" (Interviewee 7). However, children are often engaged in much the same way as more general publics:

One of my biggest eye-openers in science communication was a lecture for a class at a junior high school. At the back of the class, there were boys who thought botany was boring. I said that when I finished, they would run out in the forest and look for flowers. They just smiled arrogantly. I then demonstrated lycopodium powder ${ }^{1}$ with an unexpected explosion.

\footnotetext{
${ }^{1}$ Lycopodium is used in fireworks and explosives.
} 
After that experience, 10 of those boys from the rear of the classroom had to learn how to identify Lycopodium clavatum and similar species. It is great to surprise the backbenchers (Interviewee 15).

Interviewee 15 made another important observation: "When I was younger, I didn't do science communication aimed at children. It is about gender and position; if, as a female, you do science communication aimed at children, it sticks." However, several interviewees identified children as their target audience. These interviewees emphasized that "when you engage the interested 10- to 12-year-old, then you engage everybody" (Interviewee 11).

\section{Dialogues with affected publics}

Amateurs have always been important, especially during the 1800 s, before science was fully professionalized: "If we hadn't had all those amateurs, we would have known only a small proportion of what we know today" (Interviewee 5). Historically, amateurs have played a significant role in biodiversity mapping, and, with changes in science, it seems that amateurs have experienced a certain revival in importance after the year 2000. One reason is that some fields previously considered as professional specialisms have lost status: "Traditional taxonomy are excluded from the Norwegian Research Council" (Interviewee 5); "Floristic knowledge is no longer considered worthy of merit within the academic system. I am increasingly dependent on amateurs with a lot of field experience" (Interviewee 16).

Many interviewees, especially those recruited when taxonomy had a higher status, began their own careers as amateurs: "I ... am still a member of an amateur society ... 
(and) have also been chairperson for four years. The contact I had with professionals was important for my choice of career" (Interviewee 5). Not all of them grew up in areas with active amateur societies: "We were a couple of nerds who collected plants and animals" (Interviewee 7). Many of them said this interest stemmed from early childhood and that the amateur societies provided a learning community: "I published in the local amateur newsletter when I was young, and I am still a member" (Interviewee 2). Several told stories about how their interests changed with the community's, consequently broadening their own field of knowledge - something they have taken into their professional lives and later science communication. These old relationships also gave participants a feeling of responsibility, as they considered it important to reciprocate to their old community.

In addition, amateurs often develop their skills in collaboration with professionals; even if "most of the amateurs are self-taught" (Interviewee 10), interviewees participated in educational activities. These might involve traditional courses or learning by doing: "My most important communication with amateurs is to go through the collected material with them" (Interviewee 10). Amateurs may also have valuable skills not readily available: "Sometimes, we recruit amateurs to our projects because there aren't any peers within the university system. We have very good collaboration with amateurs within our field" (Interviewee 5). Almost all interviewees stressed the importance of having the actual specimen: "The name you assign to the observation will change over the next 10 to 50 years - that's why you need the actual specimen and not just a picture" (Interviewee 4). Some amateurs also participate in larger projects, such as the Barcode of Life Data Systems: 
Evening after evening, they can sit there and contribute their experience and observations. They also come with physical specimens ordered, identified — they might be the only experts in Norway (Interviewee 12).

Others noted that it may be time-consuming to learn a field of knowledge:

Entomology involves a lot of species; to be a good entomologist, you need to start early. We try to recruit what we have called next generation entomologists. At the same time, entomology is closely linked to botanyso you need a broad field of interest (Interviewee 1).

Consequently, it is important to see the bigger picture. Some of these working relationships are both long-lasting and crucial for doing science: "I have contact with a retired man who likes to come to the museum regularly and helps with the herbarium" (Interviewee 16); “A retired man systematically collect insects for me, and we plan together how he will do this each year" (Interviewee 1). Amateurs' contributions are perceived to be so important that some scientists reciprocate more directly: "I have worked with volunteers for 11 seasons on Spitsbergen. They are crucial for our success; species found at Spitsbergen are named after the volunteers" (Interviewee 9); "Amateur divers take pictures of species within Nudibranchia and document what they observe. We also like to have specimens. We have named a couple after the dive resort and the initiator of the Nudibranchia safaris" (Interviewee 13). Sometimes, the collaboration is at an institutional level: "I have an agreement with amateur societies that they give me the material they collect; we analyze it and return it to them" (Interviewee 7); "The friends of 
the museum buy valuable objects and donate them" (Interviewee 9). Other times, amateurs invite professionals to participate: "A local amateur society has invited me to participate in their local fieldwork. They have found some very nice specimens; however, we are also interested in the context of the specimens, so it is important that this is still intact" (Interviewee 7). These collaborative projects are often supported by the institution: "The museum supports my collaboration with the local amateur society" (Interviewee 1).

So what motivates amateurs? "Many collectors are driven by 'stamp-collecting.' They try to cover empty slots in the collection. Others are driven by aesthetic values that we seldom emphasize" (Interviewee 5). However, some interviewees found it problematic that amateurs are driven by other motives: "It is not so easy to raise amateurs; it is a different culture. They compete about findings, the first and best observer. I am a little skeptical about this; it can lead people to see more than they have actually seen" (Interviewee 4).

Several interviewees noted the "increasing expectation that we will communicate via social media" (Interviewee 11). A few use social media to communicate with a more specific community of amateurs:

I have been extremely active on the Internet since the early 1990s. What interests me most is communicating with dedicated amateurs. I am not especially interested in science communication for general publics. Those who are really dedicated will get all the backing I can manage. I have more than 1,300 members on my Facebook page. A webpage lasts longer, 
and I can reach out to more people. Much biodiversity mapping is done by amateurs-I am answering questions almost every day... I don't distinguish between working hours and spare time (Interviewee 4).

However, most interviewees use social media as only one of several channels. To a limited extent, trolls appear on social media, but only when one touches on controversial issues, such as inflicting pain on animals, arguing for the regulation of reindeer herds, protecting predators, or preventing impacts of invasive species.

While the scientists felt that the engagement aspect of Species Observation was very important, they expressed concerns about data quality: "The administration has prioritized engagement; they should have prioritized quality" (Interviewee 10). However, several interviewees use Species Observation or similar services: "I use Species Observation almost daily, looking at what has been observed and sometimes contacting the observer" (Interviewee 2). A number of related problems were mentioned. "Apparently, there are some copycats out there; if one respected person records a new observation for that location, other people do the same observation and also record it. Maybe the first two are correctly decided, then one comes in that is really far-fetched" (Interviewee 1). Some also said amateurs lack a deeper understanding of taxonomic dynamics. However, others know their followers very well: "For those specimen groups in which I am a specialist, I have fairly good knowledge about those who provide observations to Species Observation" (Interviewee 5). 


\section{Dialogues with partisan publics}

"For me, it is mostly upstream communication" (Interviewee 10). While a few others focused on upstream communication, most of the interviewees saw it as one element of a broader strategy and focused primarily on downstream communication. The partisan publics mentioned included environmental agencies and organizations, politicians, the Norwegian Biodiversity Information Center (NBIC), landholders, and professional landusers. The environmental agencies were mentioned as partners, stakeholders, and project owners (funders). It was mentioned that these agencies also influence how NBIC prioritizes its resources. The NBIC's Red and Alien Species lists are also important political issues. Species on the Red List are assigned to one of six categories, ranked by risk of extinction; species on the Alien List are ranked by their assessed impact—-both those already reproducing in Norway and the "door-knocker species." These lists naturally create controversy: "One critical issue is whether Norwegian Spruce is going to be blacklisted in those areas where it doesn't grow naturally. I am glad that a journalist introduced the concept of 'mobster spruce'2 around 2010" (Interviewee 10). Eight out of 10 interviewees have communicated directly with politicians, as in the following examples. "We named a newly discovered parasitic wasp after a politician. He took it as an honor, but not everyone understood it" (Interviewee 1). As several interviewees noted, politicians can be reached indirectly; for example, they have children, so it makes sense to communicate with those children.

As the organizer of information activities on behalf of nine amateur member organizations, the Norwegian Biodiversity Network (Sabima) is an important

\footnotetext{
${ }^{2}$ Professor Knut Fægri, a well-known botanist from University of Bergen, introduced the concept in the 1950 s.
} 
stakeholder, and several interviewees use Sabima as a channel for biodiversity information. Others participate in arrangements to facilitate healthy land use for stakeholders, such as "farmers, reindeer herders, tourist associations" (Interviewee 6). This sometimes involves highly publicized controversies that most interviewees try to avoid, especially as these are often interpreted in terms of an urban-rural divide. In this regard, a few also echoed the view voiced by Interviewee 10: "I prefer written communication; I am too quarrelsome face-to-face." In this sense, personal preference is an important aspect of science communication.

\section{Discussion}

Most interviewed scientists consider themselves a central part of their own science communication because they can share enthusiasm and passion. Consequently, they perceived science communication as an important part of their professional identities; often, highly personal variation was the norm, and all had developed their own science communication niche. Closely linked to the interviewed scientists' research activities and personal preferences, these niches have consequences for how science communication develops. Several interviewees perceived public visibility with a certain ambivalence. Only one interviewee was a "celebrity scientist," with a high level of media visibility; most had low to moderate profiles and understood science communication mostly in terms of dialogues with specific publics. Several commented that this dialogical aspect was very important because only dialogue provides a meaningful answer to the question "to what end?" However, this also means that a lot of science communication remains 
unseen to colleagues, the research field, the institutions, and society at large.

Interestingly, this study does not sustain the claim of Brossard and Lewenstein (2010) that the dissemination model (which they called the deficit model) serves as the backbone of science communication. One important reason is that this study focuses on scientists and their diversity of science communication activities, while Brossard and Lewenstein's (2010) study focused on formalized communication channels (web-based newsletters, conferences geared towards minority communities, television documentaries, and radio programs). It is quite likely that studying science communication from the scientists' perspective will give a more nuanced picture of the role of the dissemination model and a broader picture of how scientists think about science communication.

For several of the interviewees, science communication was determined not by incentives but long engagement and a sense of reciprocation to different publics and the amateur community. Consequently, several of the scientists had their own group of followers, or "science communication constituencies," and their science communication depended on those prioritized publics and scientists' own personal engagement. This broader vision must include science communication as an important quality assurance device, as most interviewed scientists ask themselves Stocklmayer's (2013) three basic questions: from whom, to or with whom, and to what end. Underlying these three questions is the key issue of relevance. The present study identified the construction of four more general science communication publics (see Table 2). 
Table 2. Types of publics constructed through museums' science communication

\begin{tabular}{|c|c|c|c|c|}
\hline & $\begin{array}{l}\text { Practices and } \\
\text { settings }\end{array}$ & $\begin{array}{l}\text { Scientists' } \\
\text { drivers }\end{array}$ & $\begin{array}{l}\text { Speaking position } \\
\text { publics }\end{array}$ & $\begin{array}{l}\text { Designated } \\
\text { outcomes }\end{array}$ \\
\hline The general public & $\begin{array}{l}\text { general } \\
\text { dissemination } \\
\text { activities often by } \\
\text { mass media } \\
\text { channels }\end{array}$ & $\begin{array}{l}\text { credibility, } \\
\text { science } \\
\text { identity, tenure }\end{array}$ & $\begin{array}{l}\text { anonymous } \\
\text { individuals, } \\
\text { initiation of } \\
\text { feedback and } \\
\text { dialogues }\end{array}$ & $\begin{array}{l}\text { public appreciation } \\
\text { of science, visibility, } \\
\text { creating attention, } \\
\text { conveying } \\
\text { knowledge and } \\
\text { process }\end{array}$ \\
\hline The pure public & $\begin{array}{l}\text { exhibitions, } \\
\text { collections, open } \\
\text { days, local venues }\end{array}$ & $\begin{array}{l}\text { personal } \\
\text { rewards, } \\
\text { broadened } \\
\text { interests }\end{array}$ & $\begin{array}{l}\text { concrete } \\
\text { individuals, naïve } \\
\text { citizen as subject of } \\
\text { education, children }\end{array}$ & $\begin{array}{l}\text { public engagement } \\
\text { with science, } \\
\text { educating citizens, } \\
\text { transforming } \\
\text { attention into } \\
\text { caring }\end{array}$ \\
\hline $\begin{array}{l}\text { The affected } \\
\text { public }\end{array}$ & $\begin{array}{l}\text { amateur naturalist, } \\
\text { amateur } \\
\text { organizations, } \\
\text { collectors and } \\
\text { observers, directly } \\
\text { or by social media }\end{array}$ & $\begin{array}{l}\text { involving the } \\
\text { public in doing } \\
\text { science }\end{array}$ & $\begin{array}{l}\text { concrete } \\
\text { individuals, the } \\
\text { authentic expert }\end{array}$ & $\begin{array}{l}\text { critical } \\
\text { understanding of } \\
\text { science, building } \\
\text { collections, } \\
\text { educating the } \\
\text { expert, knowledge } \\
\text { exchange, } \\
\text { knowledge building }\end{array}$ \\
\hline $\begin{array}{l}\text { The partisan } \\
\text { public }\end{array}$ & $\begin{array}{l}\text { organizations } \\
\text { influencing } \\
\text { knowledge building } \\
\text { and agenda setting }\end{array}$ & $\begin{array}{l}\text { funding, } \\
\text { collaboration, } \\
\text { partaking in } \\
\text { knowledge and } \\
\text { policy } \\
\text { development }\end{array}$ & $\begin{array}{l}\text { interest groups, } \\
\text { political } \\
\text { organizations }\end{array}$ & $\begin{array}{l}\text { critical } \\
\text { understanding of } \\
\text { science, } \\
\text { participation in } \\
\text { shaping new } \\
\text { knowledge and new } \\
\text { policy }\end{array}$ \\
\hline
\end{tabular}

Adapted from Braun \& Schultz 2010: 414.

Dissemination activities with general publics. Braun and Schultz (2010) state that general publics are constructed mainly through opinion polls. For museums' science communication, "general publics" refers to the whole inventory of possible publics often 
approached through different media channels, sometimes reduced to a smaller repertoire of prioritized publics, including children, families, and senior citizens. Although general publics are traditional, well known, and recognized, they encompass a series of individual adaptations, including direct communication and communication through different media - usually, a mix of both. Interviewees perceived these dialogues as invisible, hidden from institutions and society at large. Ingelfinger's rule was followed in general; however, emphasis was also placed on the importance of process and simultaneous communication between both fellow scientists and the general publics.

Although lay knowledge is sometimes associated with ignorance or conspiracy theories, none of the scientists referred to such problems in their interactions with different publics. The one exception was their concern that evolutionary theory is losing ground among some sections of the general public.

\section{Dissemination activities and dialogues with pure publics. Braun and Schultz} (2010) said that pure publics are those encountered in specific participatory arrangements. For museums' science communication, pure publics are those actively engaging in museum exhibitions, open days, and botanical garden arrangements. They are there as individuals and their main qualifications are the interests that motivate them to come. As per Braun and Schultz's (2010) study, they do not necessarily have any prior qualifications within natural history. Creating enthusiasm was perceived as very important by interviewees, as was the ability to communicate broadly. Children as publics engaged several of the interviewed scientists, both because 10- to 12-year-olds reflect the general understanding of the ideal public and because children often have low status in the context of science communication. 
Dialogues with affected publics. Braun and Schultz (2010) said that affected publics are firsthand experts affected by the issues at stake. For museums' science communication, affected publics are seen as long-lasting companions. As long as museums have existed, affected publics have contributed to natural history collections, gardens, or scientific activities. Affected publics are heterogeneous groups of amateur naturalists and friends of the museum that influence how museums and their collections evolve. Hence, amateur naturalists have a long association with natural history museums, and recent developments have revived that relationship. However, interviewees noted some differences between professional and lay knowledge. First, professionals were seen to have a deeper understanding than amateurs of the dynamics of science- the evermoving research frontier. As professionals also have access to important resources such as laboratories, professional science becomes less accessible when it moves from the field to the laboratory. On the other hand, when traditional professional knowledge, such as the floristic and faunistic, departs center stage and moves to a less prominent position, amateurs find a space where they can thrive. Because of the limited resources available for fieldwork, professional science is more concerned with general knowledge than local knowledge. On the other hand, amateurs develop extensive local knowledge that professional science sometimes needs. Consequently, lay knowledge usually conforms with scientific knowledge. However, some amateur naturalists also like to pursue aesthetic values or seek respect as an amateur naturalist by being first, doing the most, and/or being the "best." However, this competitive element is not unfamiliar to science (Conniff, 2011). Aesthetic values may simply relate to the enjoyment of natural beauty or to the beauty of a well-designed collection. In general, affected publics were seen to 
create a need for extensive dialogue, often around topics perceived as hidden from institutions and society at large.

Dialogues with partisan publics. Braun and Schultz (2010) said that partisan publics consist of organizations that hold strong opinions of the issues at stake or have particular interests. In recent times, amateur societies have become important groups, as have public authorities, such as the NBIC. Dialogues with partisan publics are perceived as important because partisan publics provide resources for research and implement policies relevant to biodiversity development. The scientists again perceived their dialogues with partisan publics as being invisible, or hidden, from the institutions and society at large.

\section{Conclusion}

Building on Braun and Schultz's (2010) four major constructions of publics, this study confirms that they are also useful in understanding museums' science communication. In the present study, museums' science communication addresses the four constructions of publics: general, pure, partisan, and affected, and the importance of dialogue is common to all. At the same time, interviewees perceived such dialogues as unseen by either institutions or society at large. Consequently, most of what they do under the "third assignment" is experienced as surprisingly unrecognized. Apparently, this is not a recent phenomenon; rather, it has characterized science communication in natural history research museums for perhaps as long as they have existed. Individuals may of course be members of all the constructed publics depending on role and context. Hence, communicating with publics is not only a question of "good," "bad," or "average" but 
also a matter of addressing different publics in relevant ways. For that reason, in addressing the quality challenge, greater attention should be paid to what is relevant for these different publics. The interviewed scientists seem to prioritize relevance as a primary quality assurance device when addressing different publics in museums' science communication.

\section{Acknowledgements}

The author thanks the 17 research scientists from the University of Oslo's Natural

History Museum and the Norwegian University of Science and Technology Museum's

Natural History collections for their participation and the two anonymous reviewers for

helpful comments. The study is made possible by grant 247611 from The Research

Council of Norway.

\section{References}

Barton R (2003) 'Men of Science': Language, Identity and Professionalization in the MidVictorian Scientific Community. History of Science 41: 73-119.

Bentley P and Kyvik S (2011) Academic staff and public communication: a survey of popular science publishing across 13 countries. Public Understanding of Science 20: 48-63.

Berman M (1978) Social Change and Scientific Organization: The Royal Institution, 1799-1844, London: Heinemann Educational Books.

Besley JC, Dudo A and Yuan S (2017) Scientists' views about communication objectives. Public Understanding of Science 2017.

Bonney R, Philips TB, Ballard HL et al. (2016) Can citizen science enhance public understanding of science? Public Understanding of Science 25: 2-16.

Bowker G (2000) Biodiversity Datadiversity. Social Studies of Science 30: 643-684.

Braun K and Schultz S (2010) "... a certain amount of engineering involved": Constructing the public in participatory governance arrangements. Public Understanding of Science 19: 403-419.

Broks P (2006) Understanding Popular Science, Maidenhead: Open University Press. 
Brossard D and Lewenstein BV (2010) A Critical Appraisal of Models of Public Understanding of Science. In: Kahlor L and Stout PA (eds) Communicating Science: New Agendas in Communication. New York: Routledge, 11-39.

Bucchi M (2008) Of deficits, deviations and dialogues: Theories of public communication of science. In: Bucchi M and Trench B (eds) Handbook of Public Communication of Science and Technology. London: Routledge, 57-76.

Cain V and Rader KA (2017) Science Communication and Museums' Changing Roles. In: Jamieson KH, Kahan D and Scheufele DA (eds) The Oxford Handbook of the Science of Science Communication. New York, NY: Oxford University Press, 205-212.

Conniff R (2011) The Species Seekers: Heroes, Fools, and the Mad Pursuit of Life on Earth, New York: W. W. Norton \& Co.

Dewey J (1927) The public and its problems, New York: Henry Bolt and Company.

Dickinson JL, Shirk J, Bonter D et al. (2012) The current state of citizen science as a tool for ecological research and public engagement. Frontiers in Ecology and the Environment 10: 291-297.

Einsiedel EF (1992) Framing science and technology in the Canadian Press. Public Understanding of Science 1: 89-101.

Epstein S (1996) Impure Science - AIDS, Activism, and the Politics of Knowledge, Berkeley: University of California Press.

Fecher B and Friesike S (2014) Open Science: One Term, Five Schools of Thought. In: Bartling S and Friesike S (eds) Opening Science. The Evolving Guide on How the Internet is Changing Research, Collaboration and Scholarly Publishing. http://book.openingscience.org.s3-website-eu-west-1.amazonaws.com/: OpeningScience.org, 17-47.

Fleck L (1935/1979) Entstehung und Entwicklung einer wissenchaftlichen Tatsache: Einführung in die Lehre wom Denkstil und Denkkollektiv (Eng. tr. Genesis and Development of a Scientific Fact), Chicago: University of Chicago Press.

Frewer LJ, Howard C, Hedderley D et al. (1999) Reactions to information about genetic engineering: impact of source characteristics, perceived personal relevance, and persuasiveness. Public Understanding of Science 8: 35-50.

Golumbic YN, Orr D, Baram-Tsabari A et al. (2017) Between Vision and Reality: A Study of Scientists' Views on Citizen Science. Citizen Science: Theory and Practice 2: 1-13.

Goodell R (1977) The Visible Scientists. The Sciences 17: 6-9.

Gross AF (1994) The roles of rhetoric in the public understanding of science. Public Understanding of Science 3: 3-23.

Harris, M (1969) The Rise of Anthropological Theory: A History of Theories of Culture. London: Routledge \& Kegan Paul.

Hesse-Biber S and Dupuis P (2000) Testing Hypotheses on Qualitative Data: The Use of HyperResearch Computer-Assisted Software. Social Science Computer Review 18: $320-328$.

Hetland P (2011) Science 2.0: Bridging Science and the Public. Nordic Journal of Digital Literacy 6: 326-339. 
Hetland P (2014) Models in Science Communication Policy: Formatting Public Engagement and Expertise. Nordic Journal of Science and Technology Studies 2: $5-17$.

Hetland P (2016) Public Communication of Technological Change: Modest and Less Modest Witnesses. Nordic Journal of Science and Technology Studies 4: 5-16.

Hetland P (2017) Rethinking the Social Contract between Science and Society: Steps to an Ecology of Science Communication. Department of Education. Faculty of Educational Sciences: University of Oslo, 214.

Hilgartner S (1990) The Dominant View of Popularization: Conceptual Problems, Political Uses. Social Studies of Science 20: 519-539.

Hine C (2008) Systematics as Cyberscience. Computers, change, and continuity in science, Cambridge, Massachusetts: The MIT Press.

Horst M (2012) Deliberation, Dialogue or Dissemination: Changing Objectives in the Communication of Science and Technology in Denmark. In: Schiele B, Claessens $\mathrm{M}$ and Shi S (eds) Science Communication in the World: Practices, Theories and Trends. Dordrecht: Springer, 95-108.

Kalleberg R (2011) The Cultural and Democratic Obligations of Universities. In: Halvorsen T and Nyhagen A (eds) Academic identities - academic challenges? American and European reflections on the transformation of higher education and research. Newcastle: Cambridge Scholars Publishing, 88-124.

Kalleberg R (2012) Sociologist as Public Intellectuals and Experts. Journal of Applied Social Science 6: 43-52.

Kullenberg C and Kasperowski D (2016) What Is Citizen Science? - A Scientometric Meta-Analysis. PLoS ONE 11.

Kyvik S (2005) Popular Science Publishing and Contributions to Public Discourse among University Faculty. Science Communication 26: 288-311.

LaFollette MC (1990) Making Science Our Own: Public Images of Science, 1910-1955, Chicago: University of Chicago Press.

Latour B (1987) Science in Action: How to follow scientists and engineers through society, Milton Keynes: Open University Press.

Leave J and Wenger E (1991) Situated Learning: Legitimate Peripheral Participation, Cambridge: Cambridge University Press.

Nieto-Galan A (2016) Science in the Public Sphere: A history of lay knowledge and expertise, Milton Park: Routledge.

Perrault ST (2013) Communicating Popular Science: From Deficit to Democracy, New York: Palgrave Macmillan.

Rognan AO (2016) En åpen og opplyst debatt om forskningsformidling? En retorisk analyse av holdninger, normer og forestillinger rundt forskningsformidling i Idadebatten. Department of Linguistics and Scandinavian Studies. Oslo: University of Oslo.

Roos M and Tønnesson J (2017) Sann opplysning? Naturvitenskap i nordiske offentligheter gjennom fire århundrer. Oslo: Cappelen Damm Akademisk.

Searle SD (2011) Scientists' communication with the general public - an Australian survey. Australian National Centre for the Public Awareness of Science. Canberra: The Australian National University. 
Smith DV, Mulhall PJ, Hart CE et al. (2016) Contemporary high-profile scientists and their interactions with the community. International Journal of Science Education 38: $1607-1621$.

Stocklmayer S (2013) Engagement with Science: Models of Science Communication. In: Gilbert JK and Stocklmayer S (eds) Communication and Engagement with Science and Technology: Issues and Dilemmas. New York: Routledge, 19-38.

Toy J (2002) The Ingelfinger Rule: Franz Ingelfinger at the New England Journal of Medicine 1967-1977. Science Editor 25: 195-198.

Treise, D and Weigold, MF (2002) Advancing Science Communication. A Survey of Science Communicators. Science Communication 23: 319-322.

Trench B (2008) Towards an Analytical Framework of Science Communication Models. In: Cheng D, Claessens M, Gascoigne T, Metcalfe J, Schiele B and Shi S (eds) Communicating Science in Social Contexts: New models, new practices. Netherlands: Springer Science+Business Media B.V., 119-135.

Yardley CB (2015) The Representation of Science and Scientist on Postage Stamps: A science communication study, Canberra: ANU Press.

\section{Author biography}

Per Hetland is Full Professor at Department of Education, University of Oslo, Norway. His research interests include public communication of science and technology, development, design and use of ICT, and science and technology policy studies. 